\title{
THE BRICK STRUCTURES OF GO THAP — TOMBS OR TEMPLES?
}

\author{
Anna Aleksandra Ślączka
}

Rijksmuseum, The Netherlands; a.slaczka@rijksmuseum.nl

\begin{abstract}
The 1980s and 1990s excavations of the archaeological site of Go Thap in the Mekong Delta resulted in unearthing a number of brick structures. In association with the structures precious objects were found, including over three hundred gold leaves. More than half of the gold leaves were decorated with pictures of men, gods, animals, weapons and auspicious objects, and some of them were inscribed. In addition to the precious objects, the structures were also reported to contain human ashes.

In the first part of this paper, I will examine the objects closely, especially the gold leaves, discovered at Go Thap. I will then compare them with similar objects originating from other archaeological sites of Southeast Asia and with objects described in traditional Indian manuals written in Sanskrit and dealing with temple architecture and temple building rituals. On the basis of this comparison, I will propose the hypothesis that the 'brick structures' unearthed in Go Thap are not tombs but remains of Hindu shrines, and the associated materials are not crematory remains but traces of consecration ceremonies performed for shrines and temples.
\end{abstract}

\section{INTRODUCTION}

Go Thap, formerly known as Prasat Pream Loven, is an area of six square kilometers with several small mounds on a dune running from northeast to southwest. It is located in the village of Thap Muoi (Tan Kieu commune, Thap Muoi district, Dong Thap province) in the Mekong Delta. The site was first explored by French archaeologists during the end of the nineteenth and at the beginning of the twentieth century. At that time, architectural material and a number of inscriptions were found including the famous so-called Gunavarman-inscription (Coedès 1931). Additional excavations followed, this time by Vietnamese archaeologists, in the 1980s, 1990s and between 2001 and 2003 (Vo Si Khai 1984; Dao Linh Côn 1984, 1993; Phạm
Nhý Hồ et. al. 2001; Lê Thị Liên et.al 2003; Lê Thị Liên 2005: 845-69, 2006: 232-244).

The 1980s and 1990s excavations resulted in unearthing eight brick structures. In association with the structures, the archaeologists found several precious objects including gold leaves, a few gold rings, some precious stones, and pieces of glass. The structures were also reported to contain human ashes.

In publications the structures have usually been referred to as 'tombs' or 'burials', with the assumption that the ashes represented cremation (Dao Linh Côn 1997:113, Higham 2001:29-31); only very rarely was doubt expressed that these features might perhaps represent something else. A few scholars carefully referred to the structures as 'worshipping places' (Le Xuan Diem et al 1995, Lê Thị Liên 2005), but the discussion about the function of these brick structures is still far from being closed.

In the first part of this paper, I will examine the objects discovered at Go Thap closely, especially the gold leaves. I will then compare them with similar objects originating from other archaeological sites of Southeast Asia and with objects described in traditional Indian manuals written in Sanskrit and dealing with temple architecture and temple building rituals. On the basis of this comparison, I will propose the hypothesis that the 'brick structures' unearthed in Go Thap are not tombs but remains of Hindu shrines, and the associated materials are not crematory remains but traces of consecration ceremonies performed for shrines and temples.

\section{OVERVIEW OF ARCHAEOLOGICAL FINDS}

The eight brick structures excavated in the 1980s and 1990s and, at that time, identified as graves, are of two distinct types. Type 1, of which three were unearthed, are structures surrounded by a rectangular brick enclosure, with 2-3 layers of bricks oriented east-west along the length. The length of the enclosures varies from 9.20 to 11 meters and the width from 6.20 to 7.75 meters. Towards the western end of the 

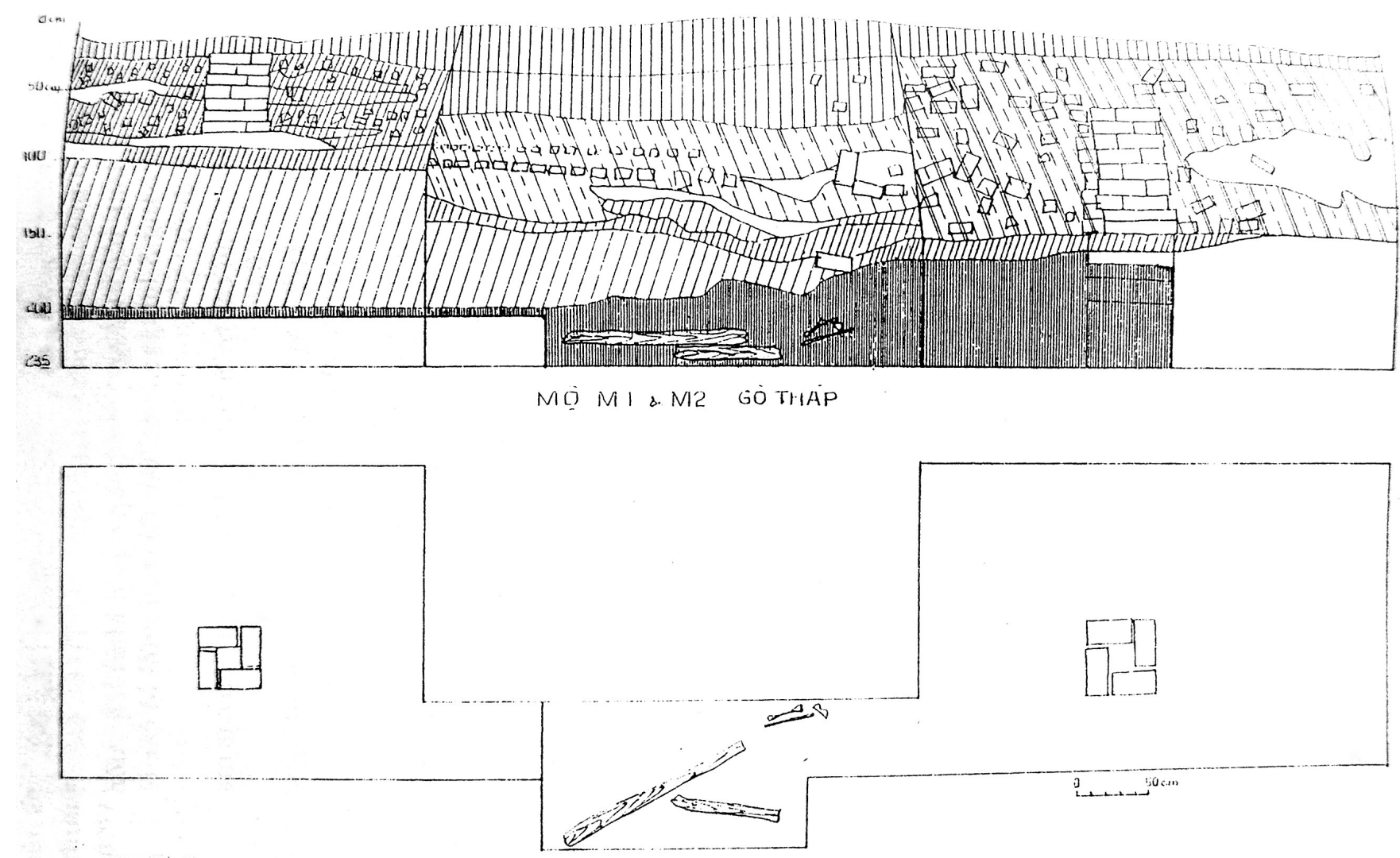

Figure 1. Cross-section and plan of the Go Thap structures (GT 84.TS.M1 and M2). From: Le Xuan Diem at al. $1995: 248$ (I would like to thank Prof. Le Xuan Diem and Dr. Le Thi Lien for the permission to use the illustrations).

enclosure, in the middle, there is a pit - often referred to as a 'grave chamber' - filled with sticky gray sand, clay and brick debris. The pit contains a brick pedestal, constructed of a few layers of bricks. Each layer consists of four bricks placed in such a way that they form a square, leaving a cavity inside (Figure 1). The cavities in the middle of the bricks are filled in the upper part with sticky gray sand and at the bottom with pure white sand. It is this layer of white sand that contained the precious objects and the supposed remains of human cremation. Type 2 structures, of which five were excavated, share the features of Type 1, but the rectangular brick enclosures are absent here (Dao Linh Côn 1997:111-113).

The brick structures yielded over 300 gold leaves, of which a great number are decorated (Figures. 2-4; see also Dao Linh Côn 1997: figures 7-9; Le Thi Lien 2005: figure 5; Lê Thị Liên 2006: plate II and figures 213, 215a, 216ab, 217a -c, 219a, 220a, 222a, 223a, 225-229a, 231). They are engraved with pictures of male and female figures, animals, weapons, and auspicious symbols.

The images of gods include Vishnu, his mount Garuda, and some female deity or deities, perhaps Lakshmi. Among the images of animals we have turtles, bulls, water-buffaloes, elephants, crocodiles, snakes and fish (Dao Linh Côn 1997; Lê Thị Liên 2005, 2006: 206-207, 2008). Many gold leaves bear images of lotuses, conches and wheels (Figure 2), which can be interpreted, depending on the context, as either the attributes of Vishnu or as auspicious symbols. Certain gold leaves were also decorated with tridents, nooses, torches, spoons and arrow-heads (Dao Linh Côn 1997: 114).

In order to interpret these finds it is necessary not to restrict the research to Go Thap, but to attempt a comparison with similar objects from regions that share several aspects with the Oc Eo culture and where, as in the Mekong Delta, Indian culture and customs mingled with the local ones. Gold leaves bearing several images are not unique to the Mekong Delta. In fact, they are quite common in the whole of Southeast Asia, and they were also found on some locations in South Asia, for instance in India: in Papanasi, Andhra Pradesh (Rao 1985: 13), and in Gokul, West Bengal (Majumdar 1935-36: 67-69); in Sahagrawa, Nepal (Mitra 1972); and on several sites in Sri Lanka (Paranavitana 1956:12-17, Plant 1914: 76). Leaves decorated with, or 


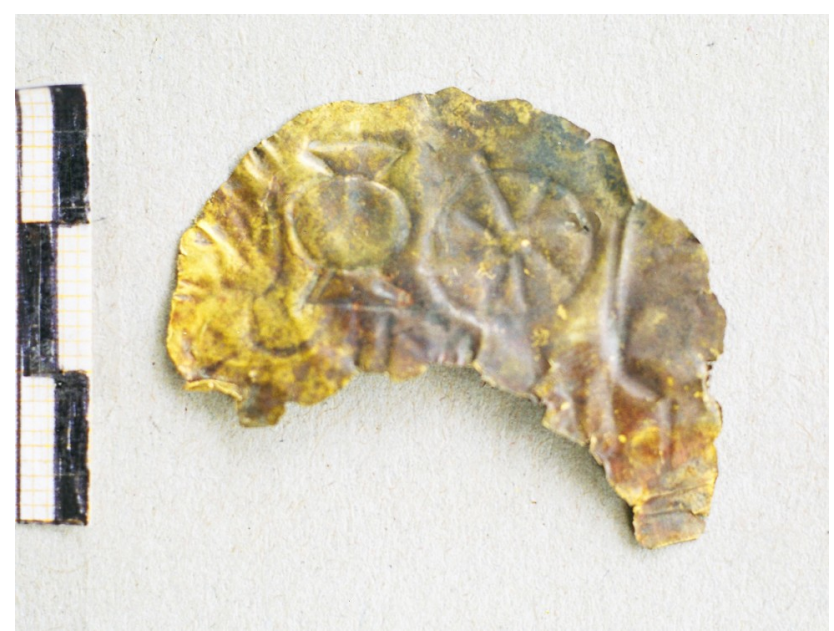

Figure 2. Gold leaves discovered at Go Thap. Photograph: Le Thi Lien.

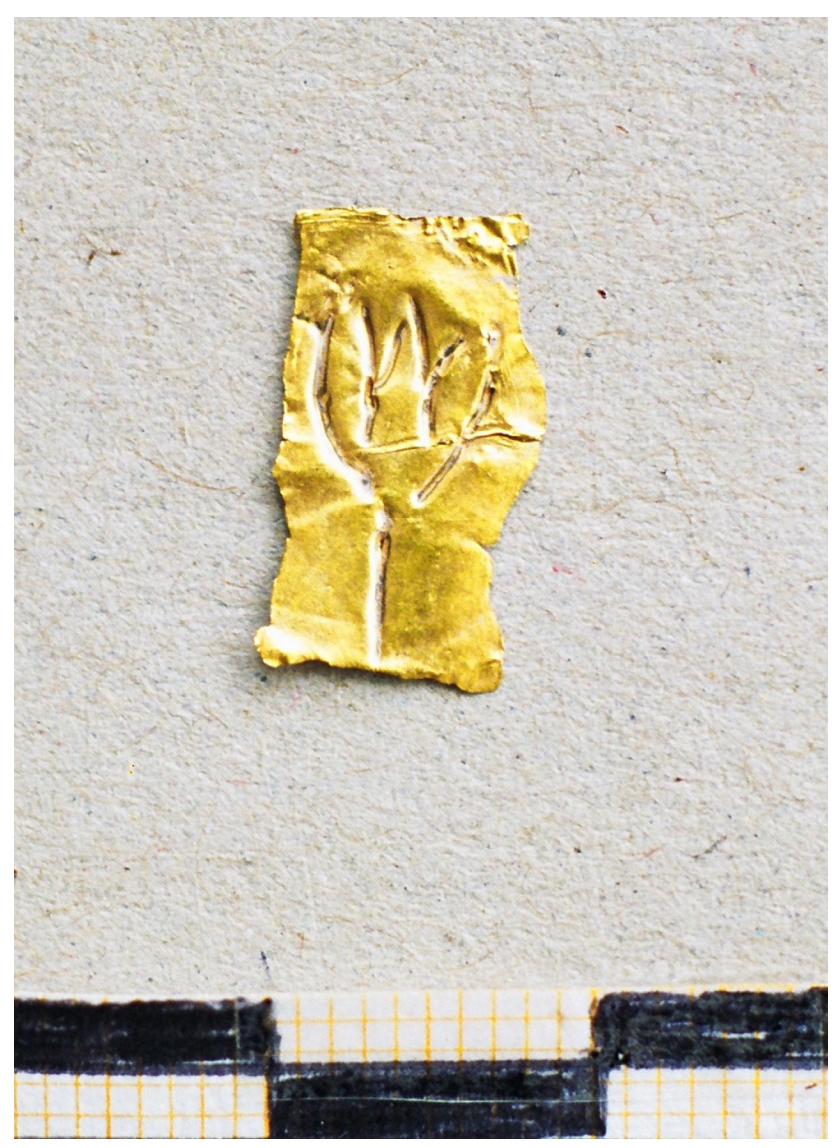

Figure 4. Gold leaves discovered at Go Thap. Photograph: Le Thi Lien.

Figure 6. Images of bulls, Chandi Bukit Batu Pahat, Malaysia. Bujang Valley Archaeological Museum, Pengkalan Bujang, Merbok, Malaysia. Photograph: Anna Ślaczka.

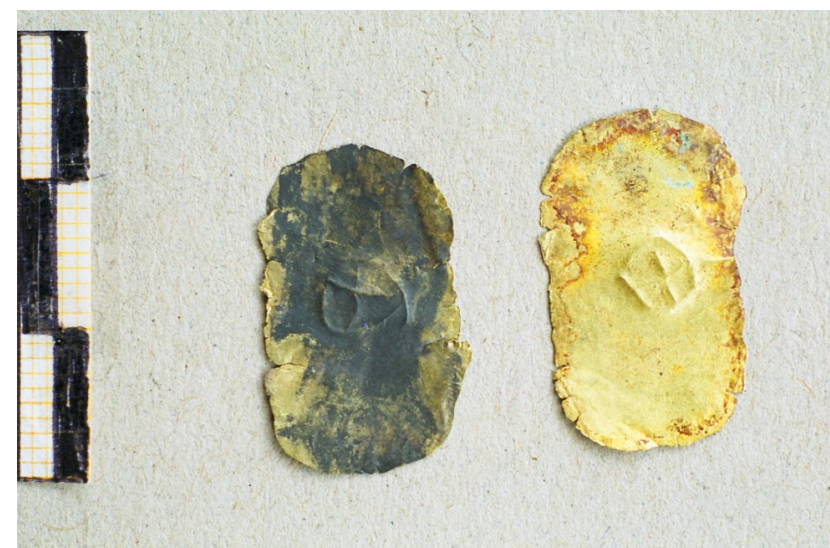

Figure 3. Gold leaves discovered at Go Thap. Photograph: Le Thi Lien.

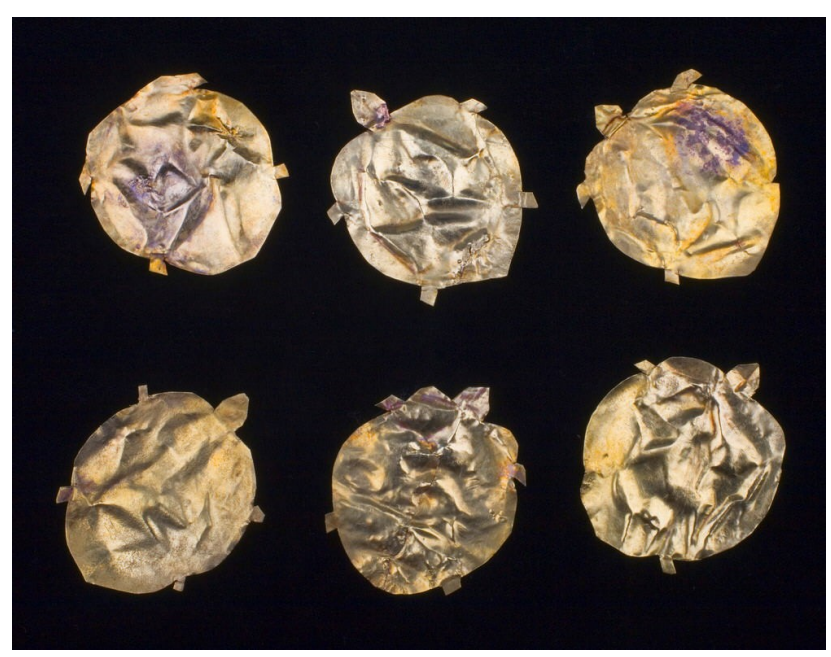

Figure 5. Images of tortoises found in Java. Museum Volkenkunde, Leiden, the Netherlands, inv. no. 1403.3200-3205.

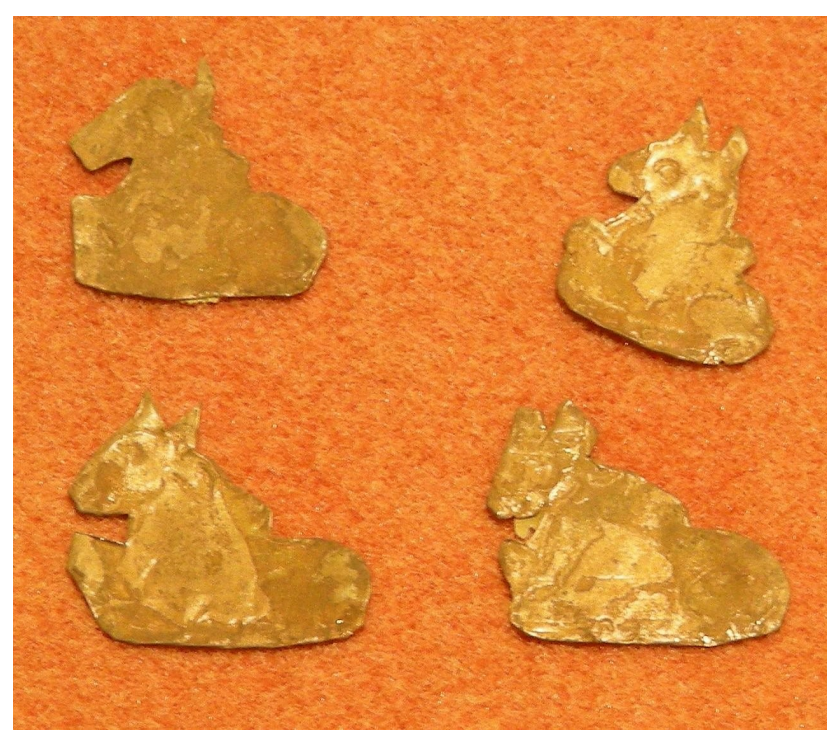




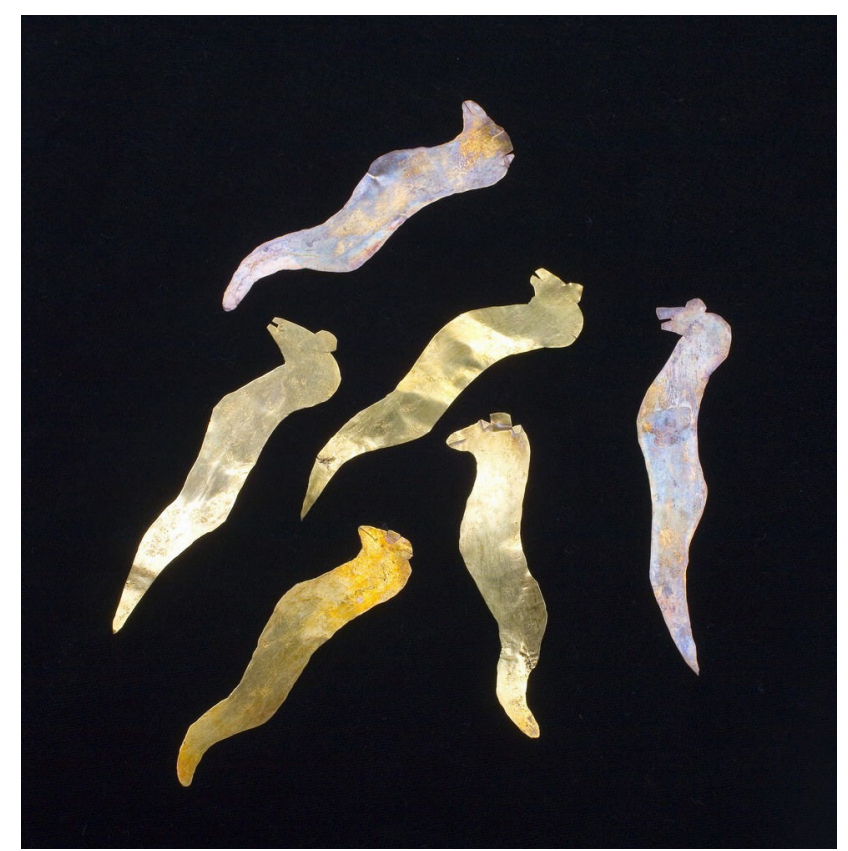

Figure 7. Images of snakes found in Java. Museum Volkenkunde, Leiden, the Netherlands, inv. no. 1403.3206-3211. Photograph: Museum Volkenkunde, Leiden.

having the shape of, lotus flowers, turtles, elephants and bulls are most frequent (Figures 5-6). In the course of my research, I could list about 20 turtles, 15 elephants, and 12 bulls, not mentioning the innumerate amount of lotus flowers (for details, see Ślączka 2007: Appendix IV). Snakes, fishes and representations of deities are less common, but do occur occasionally (Figures 7-8). In the Mekong Delta itself, figures of deities were engraved on gold leaves originated from Da Noi, An Giang province (Lê Thị Liên 2006) and Cat Tien, Lam Dong province (Nguyễn Tiến Đông 2002; Lê Thị Liên and Witzel 2008). Outside Vietnam, images of goddesses, which perhaps could be interpreted as the nine Durgas (navadurga) were found in Candi Bukit Batu Pahat in Kedah, Malaysia (Wales 1940:18-21; Ślączka 2007:305-308; see Figure 9). Gold leaves bearing images of deities are also known from Java and Kalimantan (see van Stein Callenfels 1929:26-27 and Harrisson and O'Connor 1967 respectively) and metal figurines of deities were found on several sites on Sri Lanka (see, for example: Bell 1904a and 1904b; Paranavitana 1958:48-49; Karunaratne 1984; Ślączka 2007: Appendix IV). Concerning the depictions of weapons, miniature metal and terracotta weapons were unearthed on one site in Kedah, Malaysia, and on several places in Sri Lanka (Figure 10; Wales 1940:34-36; Ślączka 2007). Those discovered in Sri Lanka were identified as the attributes of the guardians of the geographical directions (lokapala, dikpala). I think this interpretation is also valid for Kedah, and possibly Go Thap. Unfortunately, I did not have access to the complete set of photographs of the gold leaves discovered at Go Thap. Nevertheless, some objects mentioned by Dao Linh Côn as being depicted on the gold leaves of Go Thap can indeed be identified as weapons or symbols of the lokapalas. To these belong: the noose (pasha), the attribute of Varuna, the guardian of the western direction; the trident (trishula), which is the attribute of Ishana, the guardian of the northeast; and the fire or torch, which may refer to Agni, the lord of the southeast. It should be added that invocations to the lokapalas were inscribed on gold leaves found in Jolotundo, East Java (see Groeneveldt 1887:216).

\section{THE INTERPRETATION OF THE FINDS}

An important fact is - and here we enter the issue of the interpretation of the Go Thap finds - that the decorated gold leaves are not usually discovered in association with burials. Instead, they are commonly found as part of consecration deposits installed on various locations in ancient South and Southeast Asian temples. They are usually placed in foundations, often in the pit below the pedestal of the main deity, but sometimes also in walls or in the superstructures. The objects are installed there during construction as an important element of a temple consecration ritual (see Kramrisch 1946, Dagens 1994 and Ślączka 2007). In fact, almost all decorated gold leaves that I could trace were found in circumstances that left no doubt that they formed a part of a consecration deposit for a temple. There is small percentage of gold leaves of uncertain provenance, but also their association with burials seems unlikely.

The similarity between the gold leaves of Go Thap and those found within temples and temple remains in other regions of South and Southeast Asia is certainly striking. Yet it is not the only point in favor of the hypothesis that the objects originating from Go Thap are not burial finds but form a part of a consecration deposit. The location of the gold leaves-within the brick structures where they were discovered-points in the same direction. As noted above, the gold leaves of Go Thap were found in a cavity among four bricks placed on a square plan and forming the so-called pedestals contained within the pits inside the brick structures. And a number of consecration deposits found in Southeast Asian temples were located in a cavity in the middle of four bricks forming a square; the bricks themselves were placed in a square pit within the foundations. Such were the consecration deposits of Po Nagar in Nha Trang, Vietnam, found in the northwest and west tower of the temple complex; those of Prasat Trapeang Run and Prasat Ak Yom in Cambodia; and, presumably, the consecration deposits of Candi Vishnu, Central Java and Cat Tien, Lam Dong province (see Parmentier 1906, 1918, 1936; Trouvé 


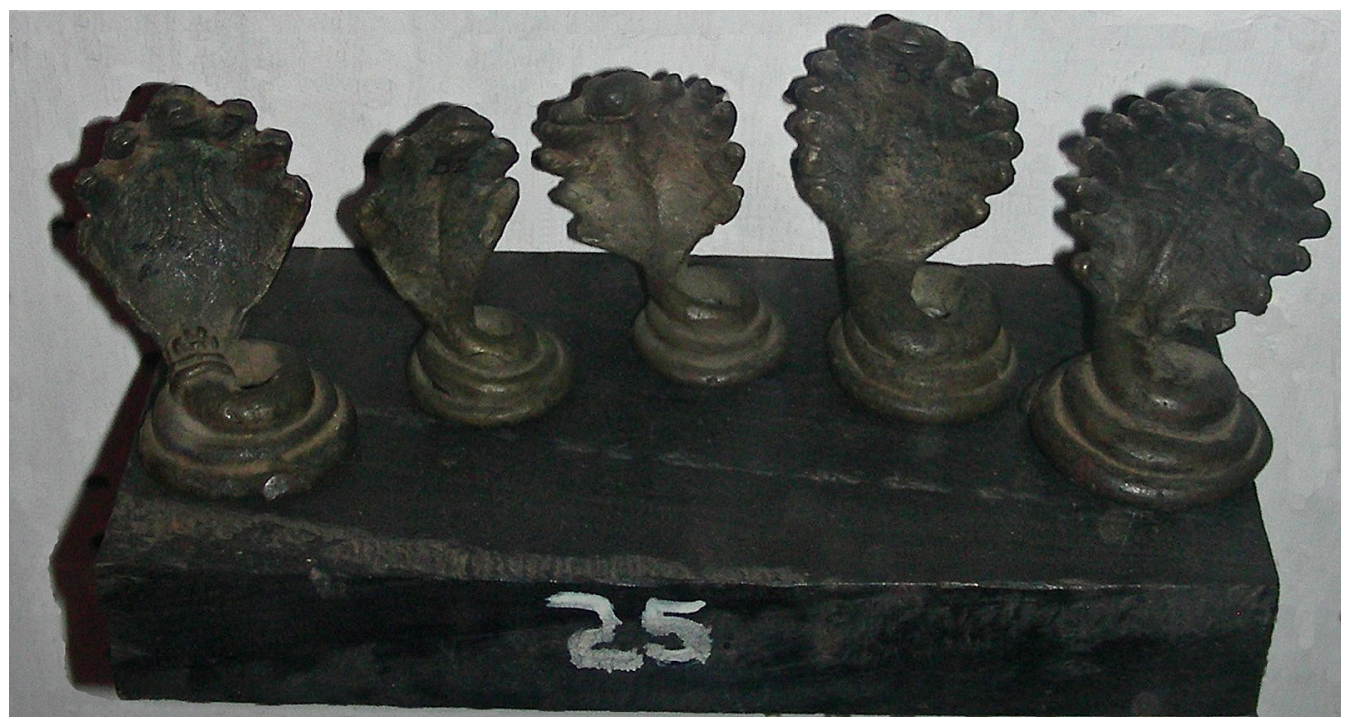

Figure 8. Bronze images of cobras. Anuradhapura Archaeological Museum, Anuradhapura, Sri Lanka. Photograph: Anna Ślaczka.

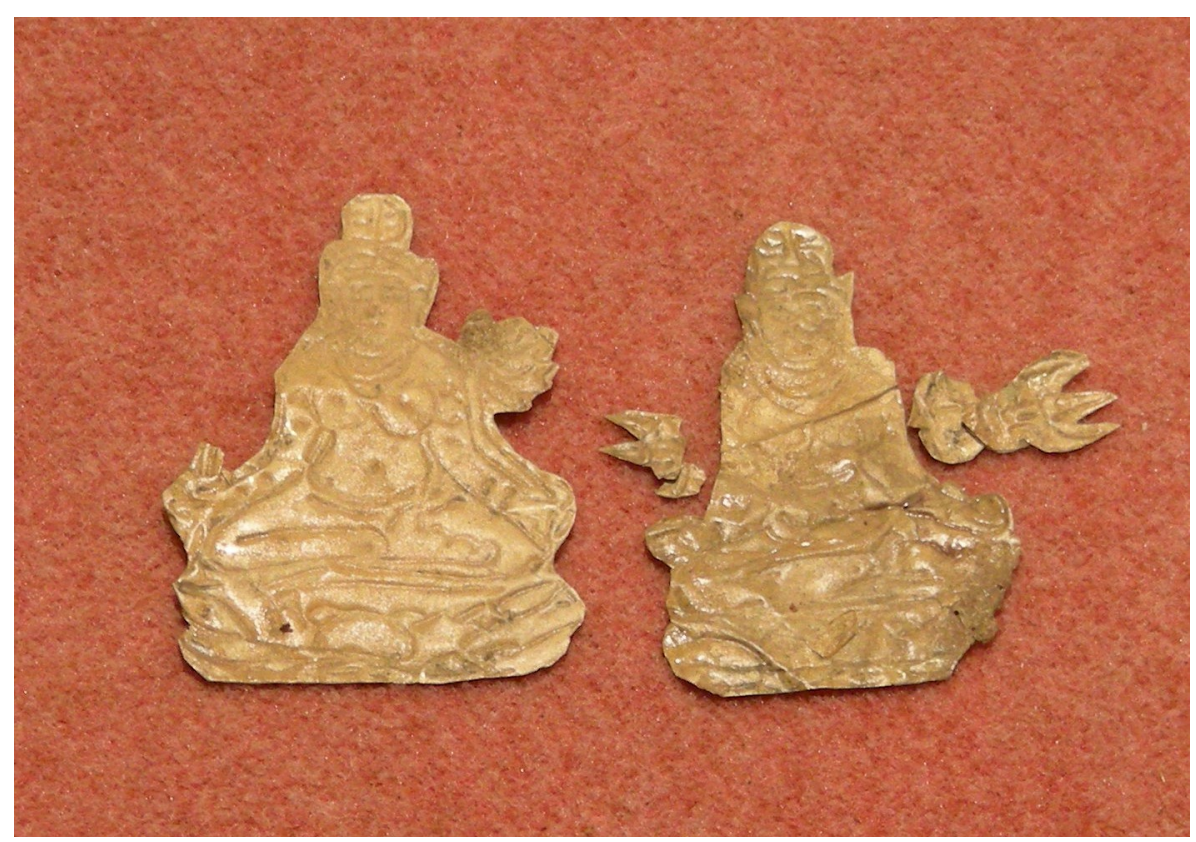

Figure 9. Images of goddesses, Chandi Bukit Batu Pahat, Malaysia. Bujang Valley Archaeological Museum, Pengkalan Bujang, Merbok, Malaysia. Photograph: Anna Ślaczka. 


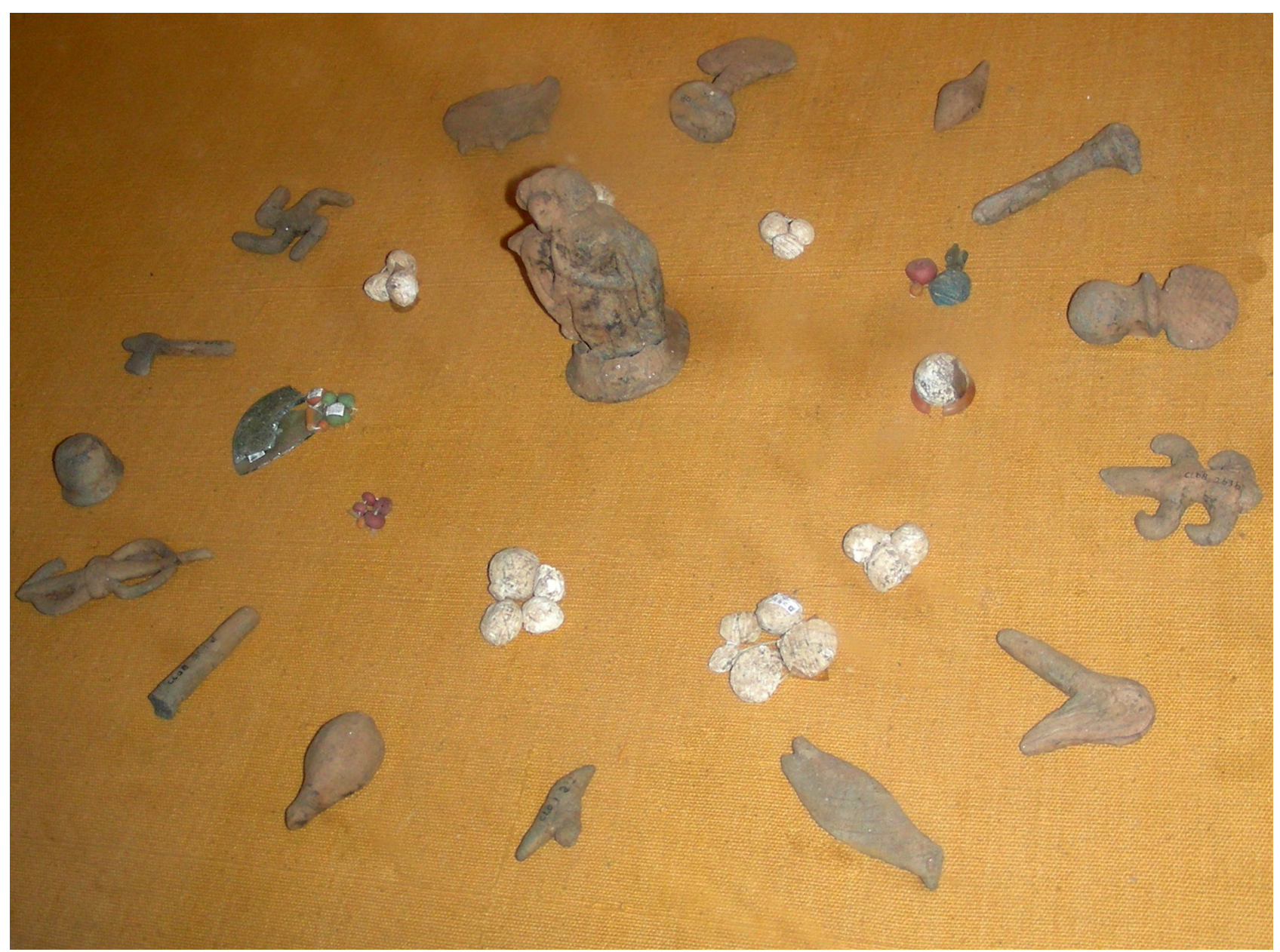

Figure 10. Auspicious symbols, miniature weapons and other items originating from a Buddhist monastery. Abhayagiri Museum, Anuradhapura, Sri Lanka. Photograph: Anna Ślaczka.

1933:1130-31; Soenarto 1985:384-388; and Nguyen Tien Dong 2002 and Le Dinh Phung 2006 respectively).

A pit or shaft containing the consecration deposit in temples is usually located directly below the pedestal of the main image in the sanctum sanctorum, which is often placed towards the west wall of the building, as temples are frequently oriented towards the East. The same can be observed in Go Thap where the 'pedestals' were located in the vicinity of the west wall. Moreover, the gold objects at Go Thap were found immersed in a layer of pure white sand. The sand was found only at the bottom of the cavity within the brick 'pedestal' and it was not present around or among the upper layers of bricks, which shows that it did not infiltrate from the outside, but was deposited there on purpose. This is an important fact. Pure white or golden sand that covers gold leaves and other items deposited in the foundation, and that differs from the sand or earth used to fill up the foundation pit, is an important characteristic of temple consecration deposits across much of Southeast Asia. It was found covering the precious items it in the consecration deposits of, for example, Angkor Vat and Vat Athvea in Cambodia, Candi Vishnu and other temples in Central Java, the site in Bongkissam in Sarawak, Kalimantan, and the temples of Dai Huu in Quang Binh, Vietnam (Trouvé 1935; Marchal 1935:480; Soenarto 1985:384-388; Harrisson and O’Connor 1967; Aurousseau 1926).

It should also be added that, as described in several archaeological reports, the images engraved on the gold leaves of Go Thap are 'badly shaped and hastily depicted' (Le Thi Lien 2005:151). And indeed, the majority of them are not very beautiful. Apart from the fact that it is not easy to engrave on thin gold leaves, this exactly is a characteristic of many items recovered from consecration deposits (not only engraved gold leaves), which - with a very few exceptions such as some of the Cat Tien finds - are described as being of poor workmanship. The reason for that 
presumably lies in the fact that consecration deposits were not meant to be seen and admired for their esthetic value. They were meant to be hidden in the foundation or the wall of a temple, and their significance and 'power' did not depend on their esthetic or even material value.

Yet another argument that supports the identification of the gold leaves of Go Thap as consecration deposits is the fact that in almost all the cases the leaves are decorated with a single image. There are only seven instances of leaves bearing more than one image (Lê Thị Liên 2005:149). This is not without significance given that during the installation of a consecration deposit, each object (here: a gold leaf decorated with a specific symbol) has to be placed separately, in a prescribed location and in a prescribed geographical direction during the recitation of an appropriate mantra.

Moreover, one should note the lack of typical 'mortuary goods' in Go Thap. No pottery or jewelry was reported from the brick structures. Finally, it should be stressed that the socalled human ashes, reportedly found along with the precious objects, were never analyzed properly. This brings in mind a similar situation in Java from several decades ago, where ancient temples were long believed to be tombs and contain human ashes. A chemical analysis of the ashes proved them to be of animal origin, which resulted in the refutation of the 'tomb-theory' (see Soekmono 1975 and 1995).

On the other hand, it is interesting to note that several ancient Sanskrit texts on architecture and ritual mention a number of consecration ceremonies that involve depositing several objects in the foundation of a building (usually a temple) and under the pedestal of an image of a deity (for an overview of these texts, see Ślączka 2007). These objects are just like those discovered at Go Thap: they include images of lotus flowers, turtles, bulls, elephants, weapons, and so forth; the guardians of the directions and their symbolism play an important role here; the items are often made of gold or gold leaf; and they are frequently deposited together with precious stones, seeds and plants. It is also interesting to add that during a consecration ceremony known as prathameshthakanyasa--the placing of the first bricks--the aforementioned items are deposited in the middle of four bricks, forming a square. The texts describing this ceremony date from a later period than the finds of Go Thap, for which various dates are given, but never later than 600 AD (Dao Linh Côn 1997:116: 380-430 CE; Higham 2001:29-31: 400-600 CE; Lê Thị Liên 2005:153: before $5^{\text {th }}$ century CE) ${ }^{1}$. Yet, the tradition of depositing precious items among four bricks is probably more ancient than the available texts, and the connection with the Sanskrit texts is, in my opinion, certainly worth attention.

As I tried to demonstrate, there are several arguments against the identification of the brick structures of Go Thap as graves. These are: the striking similarity of the gold leaves found in Go Thap to the objects that form a part of consecration deposits; the location in the middle of four bricks forming a square; the presence of the white sand; the low esthetic value of the finds; the fact that, in the majority of the cases, each leaf was decorated with a single image; the lack of typical burial goods at Go Thap brick structures; the fact that the so-called ashes were never chemically analyzed; and, finally, the possible connection with the rituals described in the Sanskrit texts.

On the basis of these arguments, I propose the hypothesis that the brick structures excavated in Go Thap are not tombs, but foundations of wooden (now deteriorated) Hindu shrines, and the gold leaves found there are remains of consecration deposits, whose installation was directly or indirectly inspired by the Indian ritual tradition as described in the Sanskrit manuals. As such, they belong to the larger Hindu-Buddhist tradition of temple building and temple consecration that prevailed in Southeast Asia until roughly the $16^{\text {th }}$ century AD.

\section{NOTES}

1. In the available English publications I could find no precise information about the samples used to obtain the radiocarbon data. Perhaps the information could be found in Vietnamese sources, to which I had no access.

\section{REFERENCES}

Aurousseau, L. 1926. Nouvelles fouilles de Dai-Hu'u (Quang -binh, Annam). Bulletin de l'École française d'Extrême Orient 26:358-369.

Bell, H.C.P. 1904a. Archaeological Survey of Ceylon: North Central Province. Annual Report 1891. Colombo: George J.A. Skeen, Government Printer.

1904b. Archaeological Survey of Ceylon: North Central Province. Annual Report 1892. Colombo: George J.A. Skeen, Government Printer.

Coedès, G. 1931. Deux inscriptions sanskrites du Fou-nan. Bulletin de l'École française d'Extrême Orient 31:1-8.

Dagens, B. 1994. Mayamata. New Delhi: Indira Gandhi National Centre for the Arts.

Dao Linh Côn 1997. The Oc Eo burial group recently excavated at Go Thap (Dong Thap Province, Viêt Nam). In Pierre-Yves Manguin (ed.), Southeast Asian Archaeology 1994: Proceedings of the 5the international conference of the European Association of Southeast Asian Archaeologists, Paris, 24th-28th October 1994, Vol. 1, pp. 111-116. Hull: Centre for Southeast Asian Studies, University of Hull. 
Groeneveldt, W.P. 1887. Catalogus der archeologische verzameling van het Bataviaasch Genootschap van Kunsten en Wetenschappen. Batavia: Albrecht and Co.

Harrisson, T. and S. O'Connor. 1967. The 'Tantric Shrine' excavated at Santubong. The Sarawak Museum Journal 15 (30-31):201-223.

Higham, Ch. 2001. The Civilization of Angkor. Berkeley: University of California Press.

Karunaratne, T.B. 1984. Garbhapâtra: Ritual deposit vessels of Buddhist shrines in ancient Sri Lanka. Ancient Ceylon 5:125-219.

Kramrisch, S. 1946. The Hindu Temple. Calcutta: University of Calcutta.

Lê Đình Phụng. 2006. Di tích Cát Tiên Lâm Đồng - Lịch sủ và Vãn hóa [Cát Tiên site in Lam Dong province History and culture], Hanoi: Social Sciences Publishing House. (In Vietnamese).

Lê Thị Liên. 2005. Gold plaques and their cultural context in the Oc Eo culture. Bulletin of the Indo-Pacific Prehistory Association 25/3:145-154.

2005. Di tích Gò Tháp và những vấn đề của vãn hoá Óc Eo [Go Thap site and the problems of Oc Eo culture], Proceeding of the International Conference: "One century of Vietnamese Archaeology”, Vol. II, pp. 845869. Hanoi: Social Sciences Publishing House, Hanoi. (In Vietnamese).

2006. Nghe thuat Phat giao va Hindu giao o Dong bang Song Cuu long truoc The ky X (Buddhist and Hindu art in the Cuu Long River Delta prior to 10th century $A D)$. Hanoi: The Gioi Publishing House.

2006. Excavations at Minh Su Mound, Go Thap site, Dong Thap Province, South Vietnam. In E. Bacus, I.C. Glover, V.C. Piggot (eds.), Uncovering Southeast Asia's past: Selected papers from the 10th International Conference of the European Association of Southeast Asian Archaeologists, pp. 232-244. Singapore: NUS Press.

2008. Hindu iconography in early history of Southern Vietnam. Mei shu shi yan jiu ji san, Di Er shi wu qi - Yuenan mei shu shi zhuan hao (Bulletin of the Fine Art Studies, 25 ${ }^{\text {th }}$ issue - Special Issue on Vietnamese Fine Art), Guo li Taiwan Da xue 25: 69-96.

Lê Thị Liên, Phạm Lý Hýõng, Nguyễn Đãng Cýờng and Nguyễn Quốc Mạnh 2003. Báo cáo khai quật lần thứ hai di chì cý trú chân gò Minh Sý [Report on the second excavation of the settlement site in Minh Su Mound], Document of Institute of Archaeology.

Lê Thị Liên and Michael Witzel. 2008. Góp phần nghiên cứu về các hiện vật kim loại vàng ở Cát Tiên-Lâm Đồng [Further study on gold artifacts found from Cat Tien site - Lam Dong province], Paper presented in the 3rd Scientific conference on Cat Tien site, Da Lat city, Lam Dong, 10th-12th December 2008. (In Vietnamese).

Le Xuan Diem, Dao Linh Con, Vo Si Khai. Van Hoa Oc Eo. 1995. Nhung kham pha mo'i [Oc Eo Culture. Recent discoveries]. Hanoi: Social Sciences Publishing House.

Majumdar, N.G. 1935-36. Excavations at Gokul. Archaeological Survey of India. Annual Records 193536:67-69.

Marchal, H. 1935. [Rapport sur les travaux de la Conservation d'Aòkor.] Athvã. Bulletin de l'École française d'Extrême Orient 35:480.

Mitra, D. 1972. Excavations at Tilaura-Kot and Kodan and explorations in the Nepalese Tarai: Report on the work undertaken in 1962 jointly by the Department of Archaeology, His Majesty's Government of Nepal, and the Archaeological Survey of India. [s.1.]: Government of India.

Nguyễn Tiến Đông. 2002. Khu di tích Cát Tiên ở Lâm Đồng [Cat Tien complex site in Lam Dong province], Ph.D thesis, Library of Institute of Archaeology. (In Vietnamese).

Paranavitana, S. 1958. The god of Adam's Peak. Artibus Asiae Suppl. no.18. Ascona: Artibus Asiae Publishers.

Parmentier, H. 1906. Nouvelles notes sure le sanctuaire de Po -Nagar, Nhatrang. Bulletin de l'École française d'Extrême Orient 6:291-300.

1918. Inventaire descriptif des monuments Chams de l'Annam. Vol. 2, Étude de l'art Cam. Paris: Leroux.

1936. La construction dans l'architecture khmère classique. Bulletin de l'École française d'Extrême Orient $35: 242-311$.

Phạm Nhý Hồ, Lê Thị Liên, Nguyễn Đình Býớng, 2001. Khai quật di chỉ cý trú chân gò Minh Sý- di tích Gò Tháp (Đồng Tháp) [Excavation of the settlement site at the foot of Minh Su Mound - Go Thap site (Dong Thap province)]. Document of Institute of Archaeology. 
Plant, G.F. 1914. Appendix C. Sigiriya Dagaba: relic chambers. Archaeological Survey of Ceylon. Annual Report 1910-11:68-70.

Rao, M.S. Nagaraja. 1985. Explorations and excavations. Indian Archaeology: A Review 1982-83, pp. 1-115. Delhi: Archaeological Survey of India.

Ślączka, Anna A. 2007. Temple consecration rituals in ancient India: Text and archaeology. Leiden: Brill.

Soekmono, R. 1975. Candi, fungsi dan pengertiannya. Le candi, sa fonction et sa conception. Bulletin de l'École française d'Extrême Orient 62:441-455.

1995. The Javanese candi: Function and meaning. Leiden: E.J. Brill.

Soenarto, Th. Aq. 1985. Temuan periuk pergunggu di Candi Sewu. Pertemuan Ilmian Arkeologi 3 (Ciloto 23-28 Mei 1983):382-389.

Stein Callenfels, van. 1929. Epigraphie en iconographie. Oudheidkundig Verslag (eerste en tweede kwartaal 1928):26-27.

Trouvé, G. 1933. [Rapport sur de dégagement du] Pr`as`at Ak Yom. Bulletin de l'École française d'Extrême Orient 33:1129-1130.

Wales, Quaritch H.G. 1940. Archaeological research on ancient Indian colonization in Malaya. Journal of the Malayan Branch of the Royal Asiatic Society 18 (1):185. 